\title{
Descripción de pruebas moleculares en el diagnóstico del virus Zika en el periodo 2008-Febrero 2018. Revisión sistemática
}

\author{
Description of molecular tests in the diagnosis of Zika virus in the period \\ 2008-February 2018
}

Juan C. Pereira-Palacioํㅜ, Lady J. Gaviria-Mejía ${ }^{1}$, Sebastián Zea-Castrillón', Patricia E Jaramillo Arbelaez ${ }^{2}$, Astrid Bedoya ${ }^{3}$

\section{Resumen}

Objetivo. Describir las pruebas moleculares usadas desde 2008 para la detección del virus Zika reportadas en artículos indexados en 3 bases de datos. Métodos. Se realizó la búsqueda de literatura científica utilizando el método PRISMA durante el periodo 2008 - febrero de 2018, en las bases de datos Pubmed, Science Direct y Embase, usando como criterios de inclusión artículos originales publicados entre los ańos 2008 a 2018 que realicen investigación en humanos con sospecha de infección por ZIKV y que describan la prueba molecular utilizada. Resultados. A partir de una búsqueda inicial de 2617 artículos recolectados con las palabras clave y aplicar los criterios de inclusión y exclusión, se seleccionan 18 artículos, de los cuales 8 son de Science Direct, 4 de Embase y 6 de Pubmed. Se describe la RT-PCR como la técnica más utilizada, se hallaron 9 blancos moleculares diferentes utilizados en las pruebas y 7 muestras biológicas de las cuales se pudo amplificar el genoma viral. Conclusiones. Hasta el momento la RT-PCR es la técnica más utilizada para el diagnóstico de la infección por el virus Zika al ser la más estandarizada y presentar una alta sensibilidad y especificidad, sin embargo se sigue trabajando sobre otras técnicas que garanticen la detección oportuna del virus, usando diferentes genes como el gen E, NS5, NS1, NS2B NS3, NS4B y CPREM principalmente en suero y orina.

Palabras clave: Zika, molecular, test, diagnóstico, detección.

\section{Abstract}

Objective. To describe the molecular tests used since 2008 for detection of Zika virus reported in indexed articles in 3 databases. Methods. A search of scientific literature was made using the PRISMA method during 2008 period - February 2018, in the databases Pubmed, Science Direct and Embase, using as inclusion criteria original articles published between 2008 to 2018 that make researches in humans with suspicion of ZIKV infection and that describes the use of molecular test. Results. From an initial search of 2617 articles recollected with the keywords and

1. Estudiantes de Microbiología y bioanalisis Universidad de Antioquia

2. Bacteriologa, Esp y MS Hematología, Docente Universidad de Antioquia, Grupo de investigación. Hematopatologia-Molecular

3. Bacteriologa. MS, Dra. Sc Ciencias Básicas Biomédicas, Docente Universidad de Antioquia, Grupo de investigación: Microbiología ambiental 
after applying inclusion and exclusion criteria, 18 articles were selected, of which 8 are from Science Direct, 4 from Embase and 6 from Pubmed. The RT- PCR was described as the most used technique, it was found 9 different molecular targets used in the tests and 7 biological samples of which the viral genome can be amplified. Conclusions. Until now the RT-PCR test is the most used technique for the diagnosis of infection for Zika virus, being the most standardized test and due it presents a high sensitivity and specificity, however there is still working about other techniques that guarantee opportune detection of the virus, using different genes like E, NS5, NS1, NS2B, NS3, NS4B y CPREM mainly in serum and urine.

Keywords: Zika, molecular, test, diagnostic, detection.

\section{Introducción}

Las infecciones causadas por virus transmitidos por vectores (arbovirus) constituyen un grupo de enfermedades emergentes y reemergentes de difícil control a nivel mundial. Entre estos, se encuentran alfavirus como Chikungunya (CHIKV), y flavivirus dengue (DENV), virus del Nilo Occidental (West Nile), Zika y fiebre amarilla, entre otros. Uno de los vectores más conocidos es el Aedes aegypti, este mosquito transmite los virus por la saliva o las heces, según el virus se multiplique dentro de las glándulas salivares o en el intestino del mosquito.

El virus del Zika es un virus envuelto de Cápside icosahédrica, perteneciente a la familia flaviviridae género flavivirus. Su genoma se clasifica en el grupo IV de la clasificación Baltimore, se compone de ARN no segmentado, monocatenario positivo que codifica para 3 proteínas estructurales y 7 no estructurales, el virión tiene un diámetro de $50 \mathrm{~nm}$ y contiene una nucleocápside rodeada por una bicapa lipídica donde se encuentran las proteínas estructurales prM/M y E que se disponen de manera icosaéedrica en la superficie (4). Aunque no se conoce muy bien la patogénesis, se cree que cuando el mosquito infectado pica al ser humano, el ZIKV atraviesa los queratinocitos y posteriormente infecta las células dendríticas que se encuentra cerca del lugar de la inoculación. Estas células presentadoras de antígeno llevan el virus hacia los nódulos linfáticos y de allí el virus se disemina al torrente sanguíneo invadiendo otros órganos, células neuronales y los trofoblastos en el feto (5). Aunque el modo de transmisión más común es la transmisión vectorial a través de la picadura del mosquito, también se sabe que existen modos de transmisión no vectorial dentro de los que se encuentran las transfusiones sanguíneas y trasplante de órganos infectados, la exposición accidental del personal de laboratorio y la transmisión sexual a través del fluido seminal. Igualmente, se conoce que existe el riesgo de transmisión vertical por paso del virus vía transplacentaria de una madre infectada hacia el feto.

Según la información suministrada por la Organización Mundial de la salud (OMS) se han registrado brotes de enfermedad por ZIKV en África, las Américas, Asia y el Pacífico. El primer gran brote se registró en la Isla de Yap (Estados Federados de Micronesia) en 2007. En julio de 2015 Brasil notificó una asociación entre la infección por el virus de Zika y el síndrome de Guillain-Barré (6), y en octubre del mismo año su asociación con la microcefalia (7). En Colombia, según el Instituto $\mathrm{Na-}$ cional De Salud en sus boletines epidemiológicos, durante los ańos 2015 a 2017, se confirmó la circulación de virus Zika en 560 municipios y cuatro distritos del territorio nacional. Se han notificado casos sospechosos de enfermedad por virus Zika en 245 municipios, sumando un total de 809 municipios con casos reportados entre confirmados y sospechosos. Desde el inicio de la epidemia en 2015 hasta 2016 se notificaron 9.799 casos confirmados y 96.860 casos sospechosos por clínica. En 2017 se notificaron un total de 2.054 casos de Zika y para la semana epidemiológica 11 de 2018 
se notificaron al Sivigila 16 casos de Zika, 12 casos de esta semana y cuatro notificados de manera tardía. Hasta marzo 11 de 2018 han ingresado 266 casos de Zika, 245 (92,1\%) casos confirmados por clínica, 19 (7,1 \%) casos sospechosos y dos casos confirmados por laboratorio (0,8 \%) (8). Aunque se evidencia una disminución de casos, al ser un virus reemergente es posible afrontar una nueva epidemia, lo que implica desarrollar formas de prevención, métodos de diagnóstico rápidos y precisos que aporten de manera oportuna la confirmación de casos por el laboratorio. Esta infección es un problema creciente de salud pública por el elevado número de personas afectadas (9).

Los síntomas más comunes del Zika son fiebre leve y exantema (erupción en la piel o sarpullido). Suele acompañarse de conjuntivitis, dolor muscular o en las articulaciones, con un malestar general que comienza entre 2 y 7 días después de la picadura de un mosquito infectado (10). Una de cada cuatro personas infectadas desarrolla los síntomas de la enfermedad y en quienes los desarrollan, la enfermedad es usualmente leve y puede durar de entre 2 y 7 días. Los síntomas son similares a los del dengue o del Chikungunya, que también son transmitidas por el mismo tipo de mosquito (11).

De acuerdo con una revisión sistemática publicada hasta el 30 de mayo de 2016, la OMS ha concluido que la infección por el virus de Zika durante el embarazo es una causa de las anomalías cerebrales congénitas, entre ellas la microcefalia, y que el virus de Zika es un factor desencadenante del síndrome de Guillain-Barré.

El diagnóstico clínico se basa en los síntomas de los pacientes y en su historial reciente (por ejemplo, si han sufrido picaduras de mosquitos o han viajado a una zona en la que se sabe que el virus de Zika está presente). La dificultad en que el diagnóstico sea solo por clínica, es que hay similitudes en los síntomas producidos por otras infecciones acusadas por arbovirus, por lo tanto, la confirmación de laboratorio es de suma importancia $(12,13,14)$.
El diagnóstico viral por el laboratorio puede realizarse mediante pruebas serológicas. Sin embargo, este diagnóstico no es totalmente fiable, ya que pueden producirse reacciones cruzadas entre las pruebas de detección del ZIKV y las que permiten detectar el virus del Nilo Occidental, los cuatro serotipos del virus del dengue y el virus de la fiebre amarilla, entre otros $(15,16,17,18,19)$.

En ausencia de un tratamiento específico y vacuna, el diagnóstico temprano es clave para controlar la epidemia y realizar una intervención oportuna. La prueba más confiable disponible se basa en métodos moleculares para la detección de ARN ZIKV a partir de muestras de fluidos corporales. Sin embargo, algunas de estas pruebas se encuentran limitadas a la fase aguda de la infección; por tanto, se debe conocer varias metodologías que permitan la utilización de diferentes tipos de muestras y la detección en diferentes estadios de la enfermedad (20). A continuación de describen las pruebas encontradas para el diagnóstico de ZIKV.

\section{Pruebas moleculares}

\section{Reacción en cadena de la polimerasa (PCR)}

La finalidad de esta técnica es la amplificación en masa de determinado fragmento de DNA por medio de un termociclador. Consiste de manera global en una serie repetitiva de ciclos, cada uno de los cuales consta de un patrón de desnaturalización (temperatura $94^{\circ} \mathrm{C}$ ), un tiempo de alineamiento del primer (temperatura de $45-55^{\circ} \mathrm{C}$ ) y un periodo de extensión (temperatura de $72^{\circ}$ C), que se logra mediante una enzima DNA polimerasa termoestable, para crear una acumulación de fragmentos específicos. El producto sintetizado en cada ciclo puede servir como patrón en el próximo número de copias de DNA, creándose una reacción en cadena que permite amplificar un fragmento específico de DNA. Esta técnica ofrece sensibilidad debido a que a partir de cantidades muy pequeñas de material genético se detecta la presencia del microorganismo en una muestra; 
ofrece especificidad ya que a través de condiciones estrictas se logra amplificar únicamente el microorganismo que se busca detectar; y ofrece oportunidad ya que permite un procesamiento rápido si se compara con otras técnicas como cultivos celulares para aislamiento de virus (21).

\section{Variantes de la PCR}

Han surgido numerosas modificaciones derivadas del método básico inicial, con el propósito de mejorar el rendimiento o la especificidad, como la PCR en tiempo real, donde el producto de amplificación es monitoreado conforme transcurre la reacción (22). En la qPCR (PCR cuantitativa) el objetivo es detectar y cuantificar las secuencias específicas de ácidos nucleicos. En la reacción en cadena de la polimerasa - transcriptasa reversa (RT-PCR) se vale de una transcriptasa reversa para realizar la síntesis de un $\mathrm{ADN}$ complementario al ARN (25). En cuanto a la PCR anidada, se trabaja con 4 cebadores, en una primera ronda se amplifica de manera convencional con los dos cebadores más externos a la región que se desea amplificar, el producto de este primer PCR se utiliza como molde para una segunda ronda que utiliza cebadores internos a la región previamente amplificada (23). Por su parte, la amplificación isotérmica mediada por LOOP (LAMP) también tiene la capacidad de amplificar fragmentos específicos de ADN o ARN. La reacción LAMP es isotérmica y amplifica el ADN del patógeno al punto de permitir una visualización directa de la reacción, por la liberación de pirofosfatos que causan turbidez (24).

El ZIKV es un virus ARN, pero las pruebas moleculares detectan y amplifican normalmente secuencias de $\mathrm{ADN}$, por lo que para el diagnóstico del ZIKV es necesario utilizar una prueba que permita la lectura de ARN como la RT-PCR, en la que se utiliza la enzima transcriptasa inversa para que el ARN pueda ser transcrito en el ADN complementario, lo que hace el análisis de PCR de moléculas de ARN posible (25).

\section{Materiales y métodos}

Se realizó una revisión sistemática de la literatura utilizando el método PRISMA (Preferred Reporting Items for Systematic Reviews and Meta-Analyses) con el propósito de determinar cuáles son las pruebas moleculares reportadas en la literatura que se utilizan para la detección del virus Zika durante el periodo 2008 a febrero 2018. La búsqueda de artículos se realizó en las bases de datos Science Direct, Embase y Pubmed ya que se considera que estas bases de datos contienen mayor información de artículos publicados sobre el tema de interés.

Utilizando los términos de búsqueda "molecular test", "diagnosis", "detection", se utiliza en conjunción con el término Zika. Se realizó la búsqueda en el periodo de 2008 a febrero 2018, en los idiomas inglés y español. Se realizó la lectura del título y resumen y se aplicaron como criterios de inclusión:

1. Artículos originales de investigación.

2. Investigación en humanos de todas las edades con sospecha de infección por el virus Zika.

3. Artículos publicados durante los años 2008 y febrero del 2018 que contengan la descripción de las pruebas moleculares utilizadas para el diagnóstico del ZIKV.

Se aplicaron como criterios de exclusión:

1. Estudios con series de casos con un $n \leq 10$,

2. Estudios moleculares que utilizan cultivos celulares de ZIKV como muestra.

La aplicación de los criterios de exclusión fue realizada por 2 investigadores de manera independiente para garantizar la reproducibilidad, realizando una socialización y discusión de las dudas con otros 2 investigadores del proyecto. En esta última 
fase se incluyeron los artículos que cumplían con todos los parámetros para realizar un análisis de la información.

Para la extracción de la información se diseñó una hoja de cálculo en formato Excel, la cual fue diligenciada por duplicado para garantizar la reproducibilidad y se analizaron las siguientes variables para cada estudio:

1. Año de publicación

2. País

3. Datos demográficos

4. Tamaño de la muestra

5. Prueba utilizada

6. Tiempo de detección

7. Tipo de muestra

8. Gen detectado.

9. Kits y primers utilizados

\section{Resultados}

En la búsqueda inicial se encontraron un total de 2.617 artículos para las tres bases de datos, de los cuales 956 fueron de Pubmed, 1025 de Science Direct y 636 de Embase. A estos artículos se les aplicaron los criterios de búsqueda en título y/o abstract, obteniendo un total de 176 artículos.

Posteriormente se eliminaron 24 artículos duplicados quedando un total de 152 artículos, a los cuales se les aplicó los criterios de inclusión, de estos, 87 correspondían a revisiones sistemáticas, comentarios y cartas al editor, 4 eran estudios realizados en animales, otros 4 eran estudios epidemiológicos y 3 se referían a investigaciones para el desarrollo de vacunas; quedando 54 artículos originales para realizar la lectura completa. Seguidamente con la aplicación de los criterios de exclusión, se encontraron 7 estudios con series de casos con un $\mathrm{n}<10,17$ estudios se realizaron in vitro con cultivos celulares, 5 estudios con solo el abstract que no pudieron ser obtenidos y 7 estudios corresponden a validaciones, con lo cual finalmente quedaron 18 artículos incluidos para extraer la in- formación. (Gráfico 1.)

De los 18 artículos seleccionados, 4 artículos (22,22\% corresponden a la base de datos Embase, 7 artículos $(38,88 \%)$ a Science Direct y 7 artículos $(38,88 \%)$ a Pubmed; el país que más estudios reportó fue Brasil con 5 estudios (27.27\%), seguido de Polinesia Francesa, Nicaragua e Italia con 2 (11.11\%) cada uno, por su parte Singapur, Bélgica, España, Colombia, Canadá, Estados Unidos y China aportaron $1(5.55 \%)$ cada uno.

Los 18 artículos fueron reportados entre los años 2012 y 2018, observándose en los ańos 2012 y 2015 un reporte $(5.5 \%)$ de estudios moleculares para el diagnóstico de ZIKV; para el periodo 2016 y 2017 se evidencia un incremento, con 6 artículos $(33.3 \%)$ cada ańo y disminuye para el 2018 con un $22.2 \%$. 
Gráfico 1. Flujograma de selección de estudios.
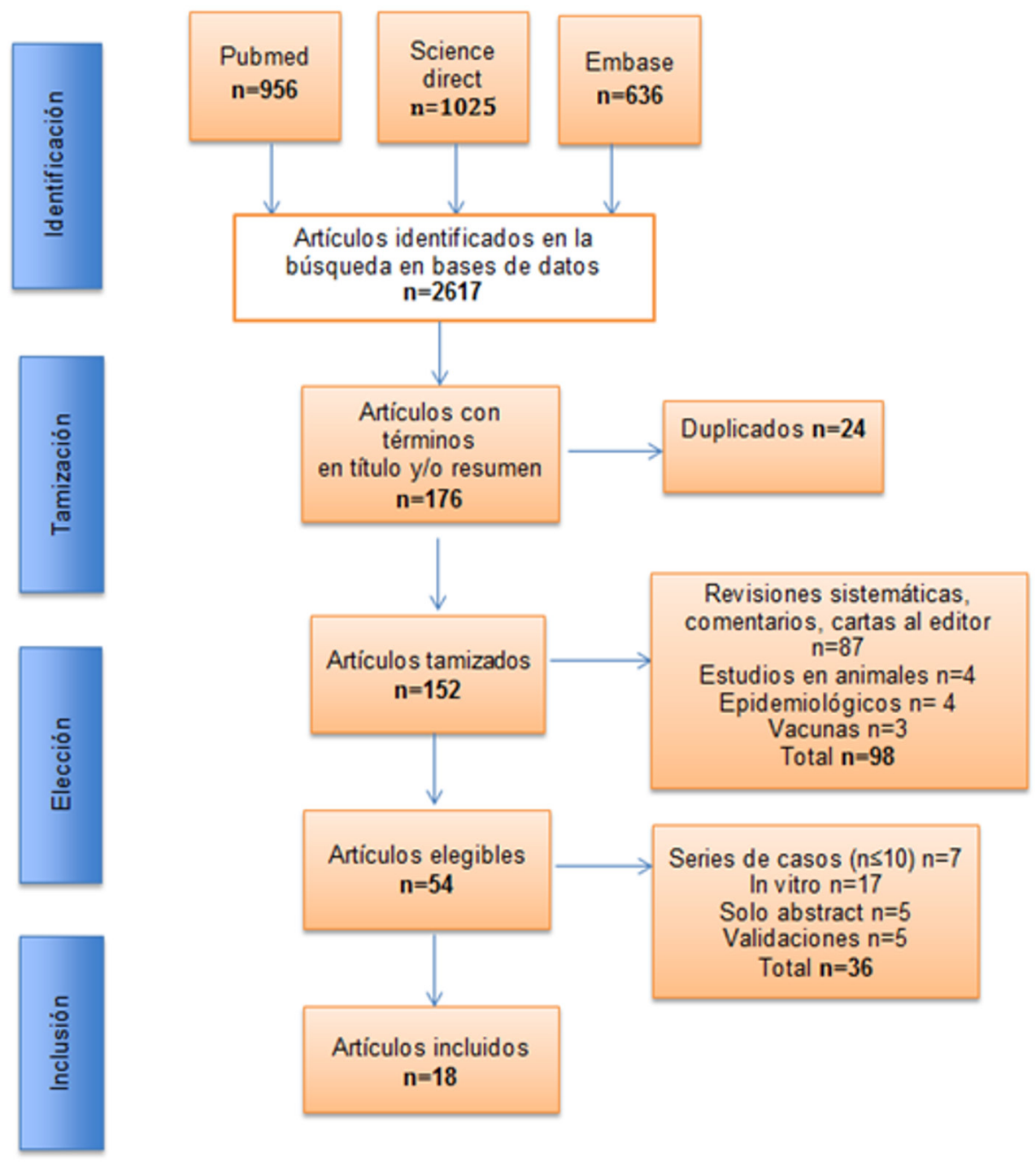

Fuente. Elaboración propia a partir de los resultados presentados.

En cuanto al tamaño de la muestra, en los 18 artículos incluidos hubo alta heterogeneidad, se calculó una mediana de 94 y un RIQ de 251 (Q1=33, Q3 =284). Se observó cómo en 8 estudios (44.4\%) utilizaron un rango de muestra entre 100-1100 participantes, mientras que en $6(33.3 \%)$ y 4 estudios (22.2\%) utilizaron rangos entre 30-100 y 10 30 respectivamente. Para la valoración del tamaño de la muestra, se utilizó el programa estadístico Epi Info y se observó que los artículos con muestras entre 100-1100 eran altamente confiables a la hora de representar una población, mientras que los estudios de 10-30 muestras podrían tener una baja confiabilidad. Sin embargo, estos fueron incluidos teniendo en cuenta que es una enfermedad reemergente y que lleva poco tiempo en el desarrollo de pruebas moleculares.

Un total de 10 artículos (55.5\%) de los estudios no reportan el dato de la edad, en los que sí es reportada se observa que el dato es variable y oscila entre 2 y 47 años de edad. Con respecto a la variable sexo, 9 estudios (50\%) no la reportaron y en el $50 \%$ restante ambos sexos son incluidos en los estudios, pero no se evidencia la proporción. 
De los 18 artículos revisados se hallaron diferentes pruebas moleculares y se pudo determinar que las técnicas más utilizadas fueron RT-PCR y RTPCR en tiempo real, las otras como la RT LAMP, la PCR anidada, la PCR en tiempo real, la PCR convencional y la PCR cuantitativa fueron usadas en un menor porcentaje. (Gráfico 2.)

Gráfico 2. Tipo de pruebas moleculares utilizada en los diferentes estudios para el diagnóstico de ZIKA.

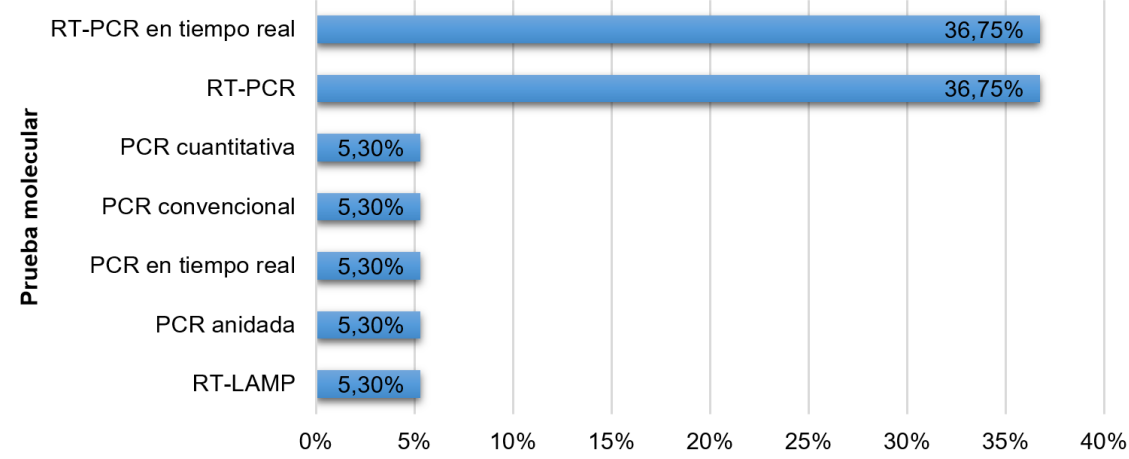

Fuente. Elaboración propia a partir de los resultados presentados. Nota: Se aclara que las técnicas PCR descritas usaron un cDNA para realizar la amplificación.

El tiempo de detección del virus desde la aparición de los síntomas hasta el momento en que se realiza la toma de la muestra para la realización de la prueba estuvo entre 1 y 8 días utilizando muestras de suero, lo que corresponde al $50 \%$ de los estudios. El 27.8\% reportó tiempo de detección en rangos más amplios cuando este fue superior a los 8 días, evidenciando detección del ZIKV hasta 32 días después de la aparición de los síntomas (26). Para estos casos utilizaron muestras de orina, saliva, semen e hisopado conjuntival. En 5 de los estudios analizados (27.8\%) no se reporta los días de detección.

Al revisar el tipo de muestras utilizadas en cada estudio, se encontró que las muestras más utilizadas para analizar la presencia del virus fueron suero y orina, seguido por la sangre total, el plasma, la saliva, el semen y el hisopado conjuntival (HC). Se encontró que en 6 estudios utilizaron dos muestras, sangre total y orina para su comparación (Ver gráfico 3)

Gráfico 3. Tipo de muestra utilizada en los diferentes estudios.

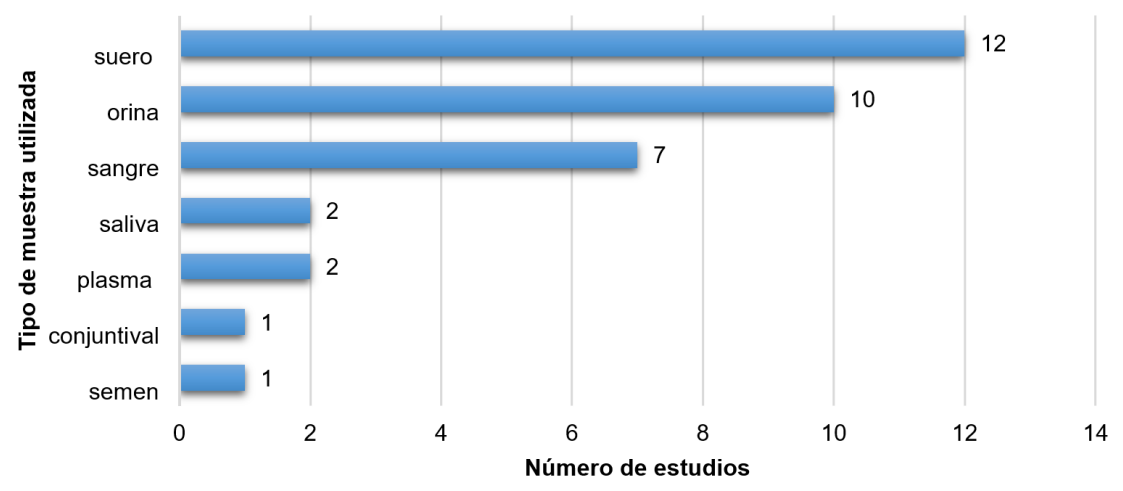

Fuente. Elaboración propia a partir de los resultados presentados. 
Del total de los estudios, el gen E fue la molécula NS2B y el NS3, NS4B y CpreM. El 19.2 \% de los más utilizada como blanco de las pruebas, en orden estudios revisados no reportaron el blanco molecudescendente encontramos el gen NS5, el NS1, el lar (Ver gráfico 4).

Gráfico 4. Blancos moleculares utilizados en las diferentes pruebas realizadas en los estudios.
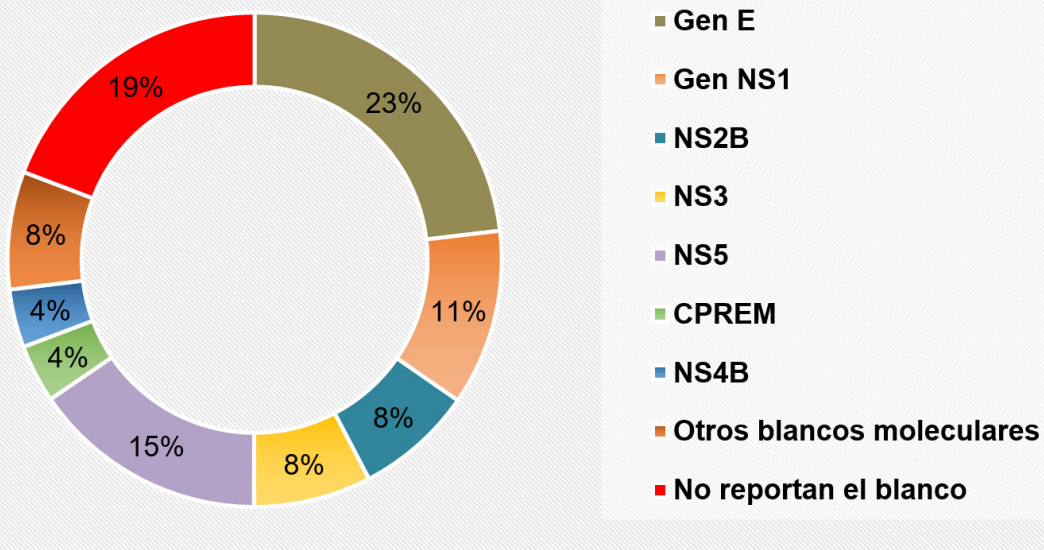

Fuente. Elaboración propia a partir de los resultados presentados.

Tabla 1. Relación técnica utilizada-blanco molecular en los diferentes estudios.

\begin{tabular}{|c|c|c|c|c|}
\hline GEN & RT-PCR & RT-LAMP & PCR ANIDADA & $\begin{array}{c}\text { PCR } \\
\text { CONVENCIONAL }\end{array}$ \\
\hline $\mathrm{E}$ & $\mathrm{X}$ & $\mathrm{X}$ & $\mathrm{X}$ & $\mathrm{X}$ \\
\hline $\mathrm{M}$ & $\mathrm{X}$ & & & \\
\hline NS1 & $\mathrm{X}$ & & & $\mathrm{X}$ \\
\hline NS2b & $\mathrm{X}$ & & & \\
\hline NS3 & $\mathrm{X}$ & & & $\mathrm{X}$ \\
\hline NS5 & $\mathrm{X}$ & & & $\mathrm{X}$ \\
\hline \multicolumn{5}{|l|}{ CPREM } \\
\hline NS4B & $\mathrm{X}$ & & & \\
\hline envolvente ZIKV & $\mathrm{X}$ & & & \\
\hline RNA viral & $\mathrm{X}$ & & & \\
\hline
\end{tabular}

Fuente. Elaboración propia.

De los estudios incluidos solo $3(17 \%)$ reportaban los parámetros de sensibilidad y especificidad. Se observó un rango de sensibilidad entre el 94$96 \%$ y un rango de especificidad de entre el $97-$ 100\%. Todos utilizaron como técnica la RT-PCR y como muestras orina, suero y sangre, tanto en la fase aguda como en la fase convaleciente temprana $(15,27,28)$.
Con respecto al límite de detección se observó que del total de artículos analizados el $61.1 \%$ de los estudios no reportan límite de detección para las pruebas y el $38.8 \%$ restante reportaron de forma muy heterogénea la unidad de medida lo cual no permitió obtener un dato homogéneo de interpretación. 
En los estudios se utilizaron una variedad de kits como:

${ }^{*}$ QIAGEN ${ }^{\oplus}$ OneStep RT-PCR

* SuperScript III Platinum One-Step qRT-

PCR kit (16.67\% de los estudios)

* RealStar Zika virus RT-PCR Kit 1.0 Altona

Diagnostics (16.67\% de los estudios)

* GoTaq ${ }^{\oplus}$ Probe 1-Step RT-qPCR System, (16.67\% de los estudios)

* Trioplex rRT-PCR (5.55\% de los estudios)

Y, finalmente, los primers más utilizados para estas pruebas fueron los descritos por Lanciotti y colaboradores (29) y por Faye y colaboradores (30). Los demás primers utilizados pueden consultarse en el artículo Assay optimization for molecular detection of zika virus (31) de Corman y colaboradores.

\section{Discusión}

En investigaciones realizadas en países de América Latina se observó que después de 2015 ocurrió un aumento significativo del número de estudios donde se investigan pruebas moleculares para la detección del ZIKV. Sin embargo, ocurrió una leve disminución en el año 2018, esto puede estar relacionado con la actualización epidemiológica del 25 agosto de 2017 en donde la Organización Panamericana de la Salud (OPS) reporta que desde la semana epidemiológica 14 del 2017 hay una tendencia decreciente de casos sospechosos y confirmados de ZIKV notificados en América del Sur (32), lo cual puede asociarse a la disminución en la tasa de transmisibilidad autóctona del virus asociado principalmente a factores ecológicos como las temperaturas templadas y la limitación de alimento para las larvas que tiene como consecuencia una menor tasa de crecimiento corporal (produciendo adultos más pequeños), y una menor tasa de desarrollo prolongando la duración del ciclo y postergando la reproducción de los individuos que afectan la persistencia del mosquito vector Aedes aegypti y que por tanto permiten una disminución en la transmisión (33).

Con relación a las pruebas moleculares para el diagnóstico de ZIKV que se han publicado hasta la fecha, se encontró que las pruebas más frecuentemente utilizadas son la RT-PCR convencional y la RT-PCR en tiempo real para amplificar 9 blancos moleculares diferentes. Ambas metodologías son las más recomendadas para amplificar virus tipo RNA como es el caso del ZIKV y son pruebas que presentan una alta sensibilidad (94-96\%) y especificidad (97-100\%) (34).

Además, en este estudio solo se encontró una investigación que desarrolló una prueba que utiliza la RT-LAMP o transcripción reversa mediada por un bucle isotérmico. Posteriormente validaron la prueba y comenzaron a utilizarla como método diagnóstico de pacientes con sospecha clínica (35). Se consideró el hecho de que no hayan más artículos evaluando muestras clínicas utilizando la RT-LAMP, porque dicha metodología es relativamente nueva y muchos de los estudios que utilizaban la prueba se centran en la fase de validación. En la búsqueda de la información se encontraron cinco artículos orientados a este tipo de prueba, pero no fueron incluidos en la revisión, porque no cumplían con los criterios de inclusión para ser revisados $(36,37,38)$.

Por otra parte, al revisar la sensibilidad y especificidad de las pruebas moleculares encontramos que solo el $17 \%$ de los estudios reportaron los parámetros de sensibilidad y especificidad, considerándolos altamente sensibles y específicos (39-43). Cabe resaltar que en estos estudios la técnica que se utilizó fue la RT-PCR y se utilizaron como muestras biológica orina, suero y sangre total; siendo esta la técnica hasta el momento más recomendada tanto en la fase aguda como en la fase convaleciente temprana (44).

Las muestras más utilizadas para el estudio son el suero y la orina, consideradas en los estudios 
como muestras adecuadas y estables para la detección del ZIKV. Sin embargo, se reportó que en suero, el genoma del virus era detectable hasta el séptimo día desde el inicio de los síntomas, según un estudio de Musso y colaboradores (45), donde se evaluó la permanencia del genoma viral en sangre y se comparó el porcentaje de detección de casos positivos de ZIKV para muestras recolectadas durante diferentes días desde el inicio de los síntomas; encontrando que el porcentaje de muestras positivas en pacientes sospechosos con Zika fue mayor en aquellos con muestras recolectadas en los primeros 7 días del inicio de los síntomas (30.8\%) comparado con las muestras que fueron recolectadas luego de este periodo de tiempo $(11.1 \%)(\mathrm{p}<0.01)(46-48)$. Sin embargo, en orina, el virus puede seguir siendo detectado hasta 21 días después del inicio de los síntomas, siendo la carga viral mayor en orina que en sangre total (49). Por otra parte, al identificar los componentes moleculares que permiten la detección del ZIKV, aun cuando en cada una de las técnicas utilizadas hay una gran variabilidad en cuanto al blanco molecular de interés, se determinó que los principales blancos moleculares son los genes $\mathrm{E}$, Ns1 y Ns5, siendo el gen E el de mayor predominio y de uso común en todas las técnicas ya que es el gen encargado de la adherencia y fusión con la membrana. (Ver Tabla1) $(15,34,50)$.

Finalmente, en el mismo estudio de Musso y colaboradores (37), se encontró que no había una diferencia estadísticamente significativa entre la carga viral detectada en mujeres ni en hombres $(\mathrm{p}=0,21)$ (siendo las diferencias estadísticamente significativas con $\mathrm{p}<0.05)$. Tampoco se observó una diferencia estadísticamente significativa entre los pacientes jóvenes o adultos $(\mathrm{p}=0,12)(32)$. Además, el estudio de Musso y colaboradores (51) también apoya esta hipótesis, pues no se observó diferencias estadísticamente significativas entre las edades medias de los pacientes que resultaron positivos para el diagnóstico de ZIKV mediante la RT-PCR. $(\mathrm{p}=0.736)(51)$.

\section{Limitaciones del estudio}

Entre las limitaciones se encuentra la poca disponibilidad de información, ya que a pesar de que se seleccionaron artículos científicos que hablaban del diagnóstico molecular en la infección por virus Zika, la mayor parte de los estudios se basan en el diagnóstico serológico, por clínica y nexo epidemiológico, y una gran cantidad de los artículos sobre diagnóstico molecular, eran estudios de validación de pruebas para diagnóstico ó estudios en los que ya se conocía el la positividad para ZIKV del paciente y se estaban evaluando por otras pruebas, por lo que en concordancia con los criterios de inclusión y exclusión que se establecieron en esta revisión sistemática, no se incluyeron (52-54).

Por otra parte, al ser la infección por el virus del Zika una enfermedad emergente, la disponibilidad de técnicas de laboratorio para diagnóstico molecular no es muy amplia o no se encuentran bien caracterizadas, lo que dificulta los criterios de selección de los artículos e inclusive las variables a analizar en ellos. Sin embargo, las variables incluidas en esta revisión abarcan los aspectos principales en cuanto al diagnóstico molecular de la infección por Zika.

\section{Conclusiones}

La PCR es la prueba molecular más utilizada en el diagnóstico virológico ya que permite la detección del genoma viral o fragmentos de él y lleva a un diagnóstico certero. Hasta el momento la RT-PCR es la más utilizada para el diagnóstico de la infección por el virus Zika no solo porque es una prueba que se ha estandarizado en muchos laboratorios, sino también porque presenta una alta sensibilidad y especificidad, garantizando un diagnóstico acertado. Sin embargo, se avecina, en cuanto al diagnóstico, el desarrollo de nuevas variantes como la RT-LAMP que permite dilucidar nuevos panoramas que pueden llevar a diagnósticos más rápidos, acertados y a menores costos. 
Aun así, hace falta hacer estudios de validación de la técnica que permitan su implementación en el laboratorio.

La muestra biológica más usada para la fase inicial de la detección viral es el suero o la sangre total, y para fase tardía la orina sería la que puede contener mayor carga viral comparada con el suero.

Los principales blancos moleculares son los genes E, Ns1 y Ns5, siendo el gen E el de mayor predominio.

El diagnóstico de la infección por el virus Zika en Colombia se realiza por medio de las características clínicas del paciente y por nexo epidemiológico, teniendo en cuenta principalmente aspectos sociodemográficos, signos y síntomas del paciente y direccionando el diagnóstico por medio de un enfoque principalmente clínico. Es por eso que es de suma importancia realizar el diagnóstico por el laboratorio mediante pruebas moleculares bien estandarizadas en las que se garantice una mayor especificidad, un diagnóstico y pronóstico oportunos, para evitar las complicaciones propias de la infección.

\section{Conflicto de intereses}

Los autores declaran que no tienen conflicto de interés.

\section{Referencias}

1. Kantor IN. Dengue, zika y chikungunya. Med. (2016);76(2):93-7.

2. OMS. Preguntas y respuestas sobre el virus de Zika y sus complicaciones [Internet]. (2017). Available from: http://www. who.int/features/qa/zika/es

3. Bobek, V., Kolostova, K., Pinterova, D., Kacprzak, G., Adamiak, J., Kolodziej, J., ... Hoffman, R. M. (2010). A clinically relevant, syngeneic model of spontaneous, highly metastatic B16 mouse melanoma. Anticancer Research, 30(12), 47994804. https://doi.org/10.1002/jmv

4. Salud, A. de M. y. (2016). Virus de Zika. Retrieved from http://www.microbiologiaysalud.org/noticias/virus-de-zika/
5. Grillet, M. E., \& Ventura, F. Del. (n.d.). Transmisión del virus Zika : Patrones y mecanismos eco-epidemiológicos de una arbovirosis, 17(2).

6. OMS. Enfermedad por el virus zika [Internet]. (2016). Available from: http://www.who.int/mediacentre/factsheets/zika/es/

7. Nogueira, M. L., Nery Júnior, N. R. R., Estofolete, C. F., Bernardes Terzian, A. C., Guimarães, G. F., Zini, N., ... Ko, A. I. (2018). Adverse birth outcomes associated with Zika virus exposure during pregnancy in São José do Rio Preto, Brazil. Clinical Microbiology and Infection, 1-7. https://doi.org/10.1016/j.cmi.2017.11.004

8. Instituto Nacional de Salud c. Boletin Epidemiologico Semanal BES. Semana Epidemiologica 11 de 2018. (2018).

9. OMS. Enfermedad por el virus zika [Internet]. (2016). Available from: http://www.who.int/mediacentre/factsheets/zika/es/

10. Alejo-Cancho, I., Torner, N., Oliveira, I., Martínez, A., Muñoz, J., Jane, M., ... Martínez, M. J. (2016). Twenty-four cases of imported zika virus infections diagnosed by molecular methods. Diagnostic Microbiology and Infectious Disease, 86(2), 160-162. https://doi.org/10.1016/j.diagmicrobio.2016.07.016

11. Waggoner, J. J., Gresh, L., Mohamed-Hadley, A., Ballesteros, G., Davila, M. J. V., Tellez, Y., ... Pinsky, B. A. (2016). Single-Reaction Multiplex Reverse Transcription PCR for Detection of Zika, Chikungunya, and Dengue Viruses. Emerging Infectious Disease Journal, 22(7), 1295. https://doi. org/10.3201/eid2207.160326

12. Cabral-Castro, M. J., Cavalcanti, M. G., Peralta, R. H. S., \& Peralta, J. M. (2016). Molecular and serological techniques to detect co-circulation of DENV, ZIKV and CHIKV in suspected dengue-like syndrome patients. Journal of Clinical Virology, 82(December 2015), 108-111. https://doi.org/10.1016/j. jcv.2016.07.017

13. Duffy, M.R., Chen, T.H., Hancock, W.T., Powers, A.M., Kool, J.L., Lanciotti, R.S., (2009) Zika virus outbreak on Yap Island, Federated States of Micronesia. N Engl J Med.360:2536-43. DOIPubMed

14. Zanluca, C., Melo, V.C., Mosimann, A.L., Santos, G.I., Santos, C.N., Luz, K., (2015) First report of autochthonous transmission of Zika virus in Brazil. Mem Inst Oswaldo Cruz.,110:569-72. DOIPubMed

15. Balmaseda, A., Zambrana, J. V., Collado, D., García, N., Saborío, S., Elizondo, D., ... Harris, E. (2018). Comparison of four serological methods and two reverse transcription-PCR assays for diagnosis and surveillance of Zika virus infection. Journal of Clinical Microbiology, 56(3). https://doi. org/10.1128/JCM.01785-17

16. Dejnirattisai, W., Supasa, P., Wongwiwat, W., Rouvinski, A., Barba-Spaeth, G., Duangchinda, T., ... Screaton, G. R. (2016). Dengue virus sero-cross-reactivity drives antibody-dependent enhancement of infection with zika virus. Nature Immunology, 17(9), 1102-1108. https://doi.org/10.1038/ ni. 3515

17. Gourinat, A.-C., O’Connor, O., Calvez, E., Goarant, C., \& 
Dupont-Rouzeyrol, M. (2015). Detection of Zika virus in urine. Emerging Infectious Diseases, 21(1), 84-86. https://doi. org/10.3201/eid2101.140894

18. Lanciotti, R. S., Kosoy, O. L., Laven, J. J., Velez, J. O., Lambert, A. J., Johnson, A. J., ... Duffy, M. R. (2008). Genetic and serologic properties of Zika virus associated with an epidemic, Yap State, Micronesia, 2007. Emerging Infectious Diseases, 14(8), 1232-1239. https://doi.org/10.3201/eid1408.080287

19. Gyurech, D., Schilling, J., Schmidt-Chanasit, J., Cassinotti, P., Kaeppeli, F., \& Dobec, M. (2016). False positive dengue NS1 antigen test in a traveller with an acute Zika virus infection imported into Switzerland. Swiss Medical Weekly, 146(February), w14296. https://doi.org/10.4414/smw.2016.14296

20. Rossini G, Gaibani P, Vocale C, Cagarelli R, Landini MP. Comparison of Zika virus (ZIKV) RNA detection in plasma, whole blood and urine - Case series of travel-associated ZIKV infection imported to Italy, (2016). J Infect [Internet]. 2017;75(3):242-5. Available from: http://dx.doi. org/10.1016/j.jinf.2017.05.021

21. Rodríguez, P. H. (n.d.). tecnicas moleculares: un avance en el diagnostico y conocimineto de patlogias oculares patricia hernandez rodriguez Ms.

22. Costa J. Reacción en cadena de la polimerasa (PCR) a tiempo real. Enfermedad Infecciosa Microbiologia Clinica [Internet]. (2004);22(5):299-305. Available from: http:// db.doyma.es/cgi-bin/wdbcgi.exe/doyma/mrevista.fulltext?pident $=13059826$

23. Erlich HA. Polymerase chain reaction. J Clin Immunol. (1989) Nov;9(6):437-47.

24. Sánchez E, Nina M, Aguirre P, Arce M, Toro N, Vilela R. Un (1) vial que contiene anticuerpo purificado con afinidad enzimática e IgG monoclonal de ratón marcado con biotina en buffer, colorante y preservante. Almacenaje a 2-8oC. (n.d.), 3-5.Amplificación isotérmica mediada por LOOP (LAMP) de ácidos nuclecios e. Rev Ciencias Farm y Bioquímicas. (2014);2:127-40.

25. Fundación Wikimedia I. Transcriptasa Inversa. 09 Marzo [Internet]. (2013);1. Available from: http://es.wikipedia.org/ wiki/Transcriptasa_inversa

26. Jia, H., Zhang, M., Chen, M., Yang, Z., Li, J., Huang, G., ... Song, T. (2018). Zika virus infection in travelers returning from countries with local transmission, Guangdong, China, 2016. Travel Medicine and Infectious Disease, 21(November 2017), 56-61. https://doi.org/10.1016/j.tmaid.2017.11.012

27. L'Huillier, A. G., Lombos, E., Tang, E., Perusini, S., Eshaghi, A., Nagra, S., ... Gubbay, J. B. (2017). Evaluation of altona diagnostics RealStar zika virus reverse transcription-PCR test kit for Zika virus PCR testing. Journal of Clinical Microbiology, 55(5), 1576-1584. https://doi.org/10.1128/JCM.0215316

28. Fascher, S., Landt, O., Niedrig, M., Pmda, Z., Cp, C., Aa, S., ... Giorgi, R. R. (2017). Rapid Molecular Detection of Zika Virus in Acute $\neg$ Phase Urine Samples Using the Recombinase Polymerase Amplification Assay. Plos Currents Outbreaks,
1-10. https://doi.org/10.1371/currents.outbreaks.a7f1db2c7d66c3fc0ea0a774305d319e.Authors

29. Lanciotti, R. S., Kosoy, O. L., Laven, J. J., Velez, J. O., Lambert, A. J., Johnson, A. J., ... Duffy, M. R. (2008). Genetic and serologic properties of Zika virus associated with an epidemic, Yap State, Micronesia, 2007. Emerging Infectious Diseases, 14(8), 1232-1239. http://doi.org/10.3201/eid1408.080287

30. Faye, O., Faye, O., Diallo, D., Diallo, M., Weidmann, M., \& Sall, A. A. (2013). Quantitative real-time PCR detection of Zika virus and evaluation with field-caught Mosquitoes. Virology Journal, 10(1), 1. https://doi.org/10.1186/1743-422X-10-311

31. Corman, V. M., Rasche, A., Baronti, C., Aldabbagh, S., Cadar, D., Reusken, C. B., ... Drexler, J. F. (2016). Assay optimization for molecular detection of Zika virus. Bulletin of the World Health Organization, 94(12), 880-892. https://doi. org/10.2471/BLT.16.175950

32. Organización Panamericana de la Salud O, Organización Mundial de la Salud O. Zika - Actualización Epidemiológica. Organ Panam la Salud/Organización Mund la Salud. 2017;15 .

33. Universidad de Buenos Aires. Factores ecológicos que afectan la persistencia y la abundancia de Aedes aegypti en la región templada [Internet]. Available from: http://server.ege.fcen. uba.ar/gem/html/investigacion_aedes factores.html

34. Colombo, T. E., Terzian, A. C. B., Júnior, J. P. A., Parreira, R., Cabrera, E. M. S., Santos, I. N. P. dos, ... Nogueira, M. L. (2018). Zika detection: comparison of methodologies. Brazilian Journal of Microbiology, 49(1), 144-147. https://doi. org/10.1016/j.bjm.2017.04.011

35. Kurosaki Y, Martins DBG, Kimura M, Catena ADS, Borba MACSM, Mattos SDS, et al. Development and evaluation of a rapid molecular diagnostic test for Zika virus infection by reverse transcription loop-mediated isothermal amplification. Sci Rep. 2017;7(1):1-10.

36. Tian, B., Qiu, Z., Ma, J., Zardán Gómez de la Torre, T., Johansson, C., Svedlindh, P., \& Strömberg, M. (2016). Attomolar Zika virus oligonucleotide detection based on loop-mediated isothermal amplification and AC susceptometry. Biosensors and Bioelectronics, 86, 420-425. https://doi.org/10.1016/j.bios.2016.06.085

37. Wang, X., Yin, F., Bi, Y., Cheng, G., Li, J., Hou, L., ... Yang, L. (2016). Rapid and sensitive detection of Zika virus by reverse transcription loop-mediated isothermal amplification. Journal of Virological Methods, 238, 86-93. https://doi.org/ https://doi.org/10.1016/j.jviromet.2016.10.010

38. Calvert, A. E., Biggerstaff, B. J., Tanner, N. A., Lauterbach, M., \& Lanciotti, R. S. (2017). Rapid colorimetric detection of Zika virus from serum and urine specimens by reverse transcription loop-mediated isothermal amplification (RT-LAMP). PLoS ONE, 12(9), 1-16. https://doi.org/10.1371/journal. pone. 0185340

39. Bernal Luz Mery, López Greizy. Diagnóstico prénatal: retrospectiva. Nova. 2014; $12(21)$ : 23-36. 
40. Márquez Gómez Marco Antonio, Gómez Díaz Graciela María. Accidente ofídico en el departamento de Sucre, Colombia. Nova. 2015; $13(24)$ : 39-46.

41. Pinilla B Gladys, Chavarro P Bibiana, Moreno A Natalia, Navarrete $\mathrm{O}$ Jeannette, Muñoz M Liliana. Determinación de los genes, 16S ADNr, polA, y TpN47, en la detección de Treponema pallidum subsp. pallidum para el diagnóstico de sífilis congénita. Nova. 2015; 13( 24 ): 17-25.

42. Corrales Lucia Constanza, Antolinez Romero Diana Marcela, Bohórquez Macías Johanna Azucena, Corredor Vargas Aura Marcela. Bacterias anaerobias: procesos que realizan y contribuyen a la sostenibilidad de la vida en el planeta. Nova. 2015; $13(24): 55-81$

43. González Yuri Lilian. Evaluación de la percepción del riesgo ocupacional en trabajadores de una empresa del sector de la construcción en Bogotá D.C. Nova. 2015; 13( 23 ): 93-107.

44. Abd El Wahed, A., Sanabani, S. S., Faye, O., Pessôa, R., Patriota, J. V., Giorgi, R. R., ... Weidmann, M. (2017). Rapid Molecular Detection of Zika Virus in Acute-Phase Urine Samples Using the Recombinase Polymerase Amplification Assay. PLoS Currents, 9, ecurrents.outbreaks.a7f1db2c7d66c3fc0ea0a774305d31. https://doi.org/10.1371/currents.outbreaks.a7f1db2c7d66c3fc0ea0a774305d319e

45. Musso D, Rouault E, Teissier A, Lanteri MC, Zisou K, Broult $\mathrm{J}$, et al. Molecular detection of Zika virus in blood and RNA load determination during the French Polynesian outbreak. J Med Virol. 2017;89(9):1505-10.

46. Carrero Sandra Helena Suescún, HerediaMontoya Dina Paola, Bolańos Yoryany Mulato, Medellín Martín Orlando Pulido. Seroprevalencia de infección por Leptospira y factores de riesgo en estudiantes de una universidad de Colombia. Nova. 2017; $15(27$ ): 131-138.

47. Naranjo Flórez Ricardo Andrés. Avances y perspectivas en Síndrome de Asperger. Nova. 2014; 12( 21 ): 81-101.

48. Zuluaga Martha, Robledo Sebastian, Osorio-Zuluaga German A, Yathe Laura, Gonzalez Diana, Taborda Gonzalo. Metabolomics and pesticides: systematic literature review using graph theory for analysis of references. Nova. 2016; 14( 25 ): 121138.

49. George, K. S., Sohi, I. S., Dufort, E. M., Dean, A. B., White, J. L., Limberger, R., ... Zucker, A. (2017). crossm Zika Virus Testing Considerations : Lessons Learned from the First 80 Real- Time Reverse Transcription-PCR-Positive Cases Diagnosed in New York State, 55(2), 535-544. https:/doi. org/10.1128/JCM.01232-16

50. Calvo, E. P., Sánchez-Quete, F., Durán, S., Sandoval, I., \& Castellanos, J. E. (2016). Easy and inexpensive molecular detection of dengue, chikungunya and zika viruses in febrile patients. Acta Tropica, 163, 32-37. https://doi.org/10.1016/J. ACTATROPICA.2016.07.021

51. Musso, D., Roche, C., Nhan, T. X., Robin, E., Teissier, A., \& Cao-Lormeau, V. M. (2015). Detection of Zika virus in saliva. Journal of Clinical Virology, 68, 53-55. https://doi.org/10.1016/j.jcv.2015.04.021
52. Ávila de Navia Sara Lilia, Estupiñán-Torres Sandra Mónica, Díaz González Liliana. Calidad bacteriológica del agua Vereda El Charco, San Miguel de Sema, Boyacá- Colombia. Nova. 2016; 14( 25$)$ : 139-145.

53. Almonacid Urrego Carmen Cecilia, Camarillo Romero María del Socorro, Gil Murcia Zulay, Medina Medina Claudia Yasmin, Rebellón Marulanda Jennifer Viviana, Mendieta Zerón Hugo. Evaluación de factores de riesgo asociados a enfermedad cardiovascular en jóvenes universitarios de la Localidad Santafé en Bogotá, Colombia. Nova. 2016; 14(25): 9-17.

54. González Devia Johanna L., Monroy Romero Paola A., Almonacid Urrego Carmen C.. Homocisteína y otros factores de riesgo cardiovascular en niños de educación básica primaria del Colegio Distrital Manuel Elkin Patarroyo, Bogotá, D.C. Colombia. Estudio piloto. Nova. 2017 ; 15( 27 ): 103-117. 